\title{
Fibroepithelial polyps of the vagina: Are they old granulation tissue polyps?
}

T B Halvorsen, E Johannesen

\begin{abstract}
Aims: To study the nature of fibroepithelial polyps of the vagina.

Methods: Sixty five fibroepithelial polyps of the vagina and 64 granulation tissue polyps diagnosed over 15 years were reviewed histologically.

Results: Cytologically benign multinucleated stromal cells were present in large numbers in 19 of the fibroepithelial polyps of the vagina (FEPV). Only one polyp contained atypical stromal cells, a high mitotic count, and abnormal mitoses and was indistinguishable from $a$ malignant tumour. Immunostaining showed the presence of vimentin and desmin positive mono- and multinucleated stromal cells in FEPV and occasional oestrogen receptor positive nuclei. Desmin positive cells could not be shown in granulation tissue polyps.

Conclusions: FEPV are common lesions with benign mono- and multinucleated fibroblastic stromal cells in which myoid differentiation is often present. FEPV may develop as a result of a granulation tissue reaction after some local injury of the vaginal mucosa. Hormonal factors may modulate the growth of FEPVs. Delayed differentiation of myofibroblastic cells may explain why granulation tissue sometimes does not contract properly but turns into polyps.
\end{abstract}

Fibroepithelial polyps of the vagina (FEPV) are mucosal polypoid lesions with a connective tissue core covered by a benign squamous epithelium. They are thought to be rare. ${ }^{1-3}$ FEPV have attracted special interest during the past decades because of the presence of atypical cells and abnormal mitoses in some of them..$^{2-6}$ Because of a striking histological similarity to some highly malignant vaginal tumours, such FEPV have been classified as "pseudosarcomas" and "pseudosarcoma botryoides". ${ }^{25-8}$ The danger of misdiagnosing such lesions as frankly malignant has been emphasised by many authors, but ever since the first detailed description of FEPV with atypical stromal cells by Norris and Taylor in $1966^{4}$ the benign nature of the lesions has repeatedly been confirmed. ${ }^{2-8}$ Despite thorough light microscopic studies with conventional staining techniques and electron microscopic and immunohistochemical studies, ${ }^{1-12}$ the pathogenesis of FEPV and the true nature of their stromal cells remain uncertain. As it has been our impression that
FEPV are neither rare nor do they usually represent serious diagnostic problems with respect to malignant lesions, we decided to review all the vaginal polypoid tumours recently diagnosed in our department, paying special attention to FEPV and their relation to granulation tissue polyps.

\section{Methods}

Histological material from all polypoid primary vaginal lesions diagnosed between 1976 and 1990 was retrieved from the files at the Department of Pathology, Trondheim University Hospital, a general regional hospital with 1000 beds. During the study period our department received from 15000 (in 1976) to 23000 (in 1990) biopsy specimens, one third of which came from our hospital and the rest from other hospitals and medical practitioners in the midNorway region.

Clinical data and macroscopic details were obtained from the surgical pathology reports. Follow up data on a pregnant woman with an atypical polyp were obtained from her gynaecologist.

\section{CONVENTIONAL LIGHT MICROSCOPY}

The original sections were re-examined by one of us (TBH). They had been cut at $5 \mu \mathrm{m}$ thickness from formalin fixed and paraffin wax embedded biopsy specimens and were stained with haematoxylin and eosin and saffron (HES). The review yielded 149 lesions. Six condylomas, six leiomyomas, four epithelial cysts, three haemangiomas and one benign fibrous histiocytoma were excluded from this study. The remaining 129 polyps were classified on the basis of the predominant stromal component. Polyps comprising mostly granulation tissue were classified as granulation tissue polyps. The others were classified as FEPV and subdivided into four histological types: collagenous (fig 1); myxoid (fig 2); mixed (when substantial proportions of more than one stroma type were present); and atypical (when containing cytological features that were indistinguishable from those of malignant cells).

The number of multinucleated cells, mast cells, and mitoses were assessed semiquantitatively: $0 /+=$ none or sparse, and $++=$ many. The overall cellularity was estimated as relative to that of the normal vaginal mucosa: low/normal and high.

\section{IMMUNOHISTOCHEMISTRY}

Five cases of collagenous, myxoid, and mixed FEPV, and five granulation tissue polyps were 


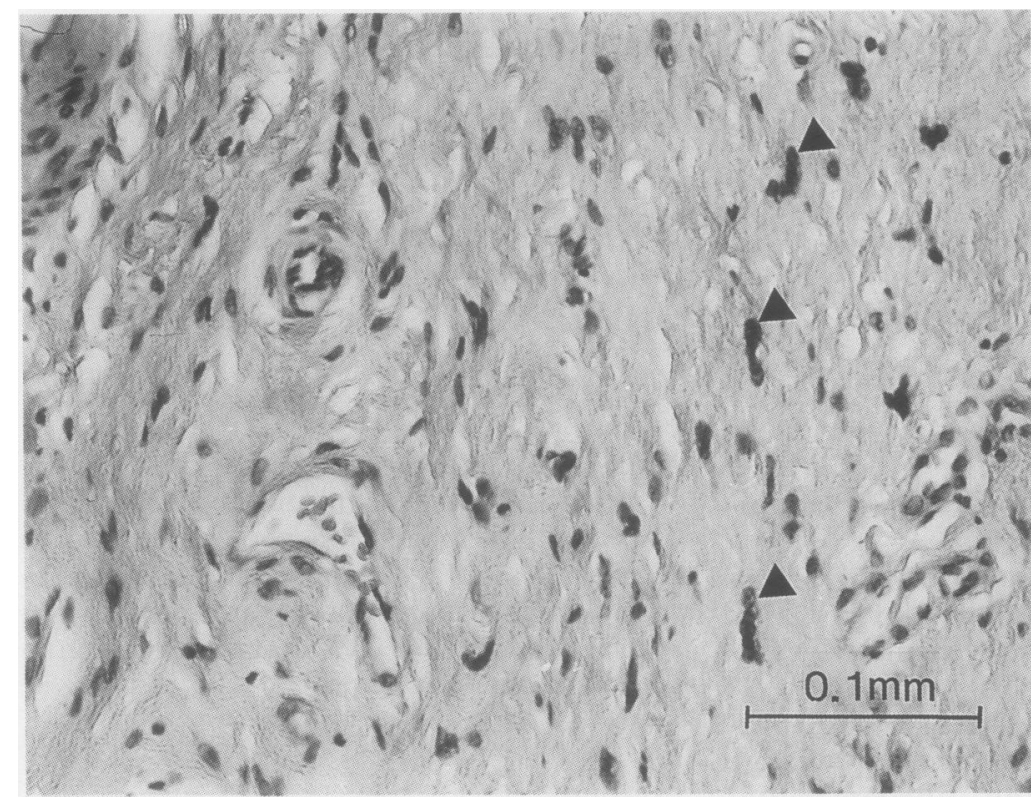

Figure 1 The stromal component in a collagenous FEPV. Several blood vessels are seen (left). Note multinucleated cells with overlapping nuclei and sparse cytoplasm (arrowheads) (HES).

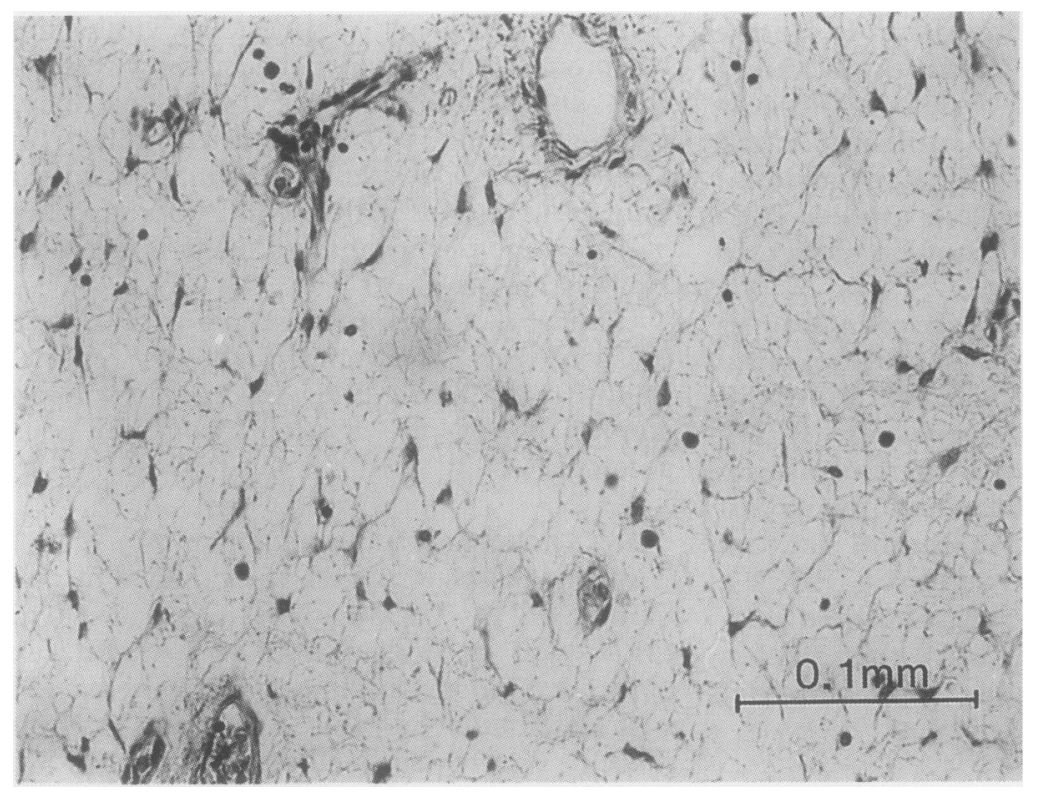

Figure 2 The stromal component in a myxoid FEPV, with spindle and stellate stromal cells in a loosely textured connective tissue matrix (HES).

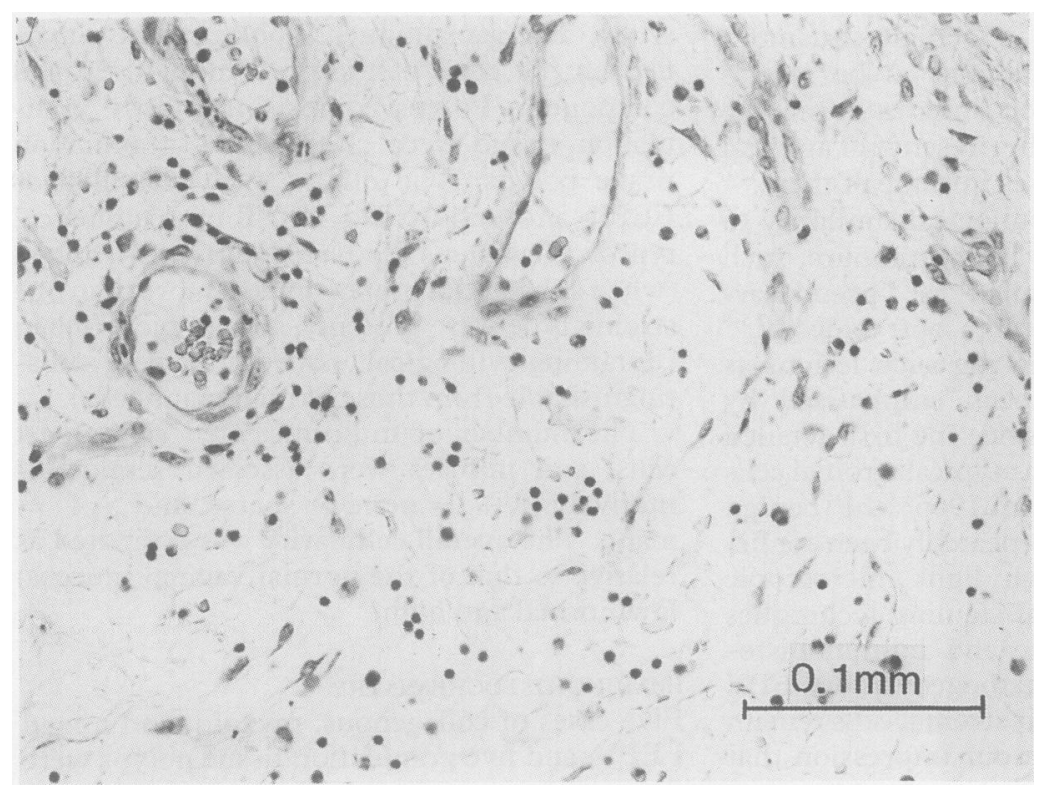

Figure 3 A myxoid area (lower half) in a granulation tissue polyj (HES). randomly selected for immunohistochemical examination together with one atypical polyp. Sections $5 \mu \mathrm{m}$ thick were cut from stored paraffin wax blocks. Dewaxed sections were immunostained using an indirect peroxidaseanti-peroxidase (PAP) method $^{13}$ with minor modifications for detection of $\alpha$-1-antitrypsin (AAT), myoglobin, muramidase (lysozyme) and oestrogen receptor; an avidin-biotin peroxidase complex $(\mathrm{ABC})$ method $^{14}$ was applied for immunostaining with antibodies against vimentin and desmin using the Vectastain kit (Vector Laboratories, Burlingame, California, USA). The following antibodies were used: monoclonal mouse anti-vimentin (batch 036, dilution 1 in 100, Dakopatts Ltd, Denmark); monoclonal mouse anti-desmin (batch 076, dilution 1 in 100, Dakopatts Ltd, Denmark); monoclonal rat anti-oestrogen receptor (batch $48374 \mathrm{M} 300$, dilution 1 in 1 from a separate kit provided by Abott Laboratories, North Chicago, Illinois); polyclonal rabbit anti-AAT (batch 0298, dilution 1 in 100, Dako Immunoglobulin Ltd, Denmark); polyclonal rabbit anti-myoglobin (batch 044-P, dilution 1 in 200, Dako Corporation, Santa Barbara, California, USA); and polyclonal rabbit anti-muramidase (lysozyme) (batch 034, dilution 1 in 50, Dako Immunoglobulin Ltd, Denmark). Positive controls were sectioned from archival blocks with biopsy specimens of known histology. The immunohistochemical staining of the stromal cells was scored as follows: $0=$ no staining, $+=$ positive staining.

\section{Results}

FEPV and granulation tissue polyps were equally common in this series: there were 30 collagenous FEPV, 19 myxoid FEPV, 15 mixed FEPV, one atypical FEPV, and 64 granulation tissue polyps. Altogether, 12 polyps contained small areas with a stromal component that differed from the predominating one. Numerous young blood vessels and occasional inflammatory infiltrates were common findings in FEPV. Some granulation tissue polyps contained myxoid areas mimicking the myxoid stroma of FEPV (fig 3).

The mean age of the patients was 46.5 (SEM 1.6) years (range 4 to 85 years). Patients with granulation tissue polyps and FEPV had similar mean ages and ranges.

One hundred and seven $(83 \%)$ of the polyps were discovered incidentally during vaginal examination; 16 polyps (10 granulation tissue polyps and six FEPV) had caused a bloody discharge, and six polyps (four granulation tissue polyps and two FEPV) had been felt as a mass or had caused some local discomfort. Information on a recent gynaecological operation involving the vaginal mucosa, or a recent delivery was available in 48 of $64(75 \%)$ granulation tissue polyps compared with 11 of 65 $(17 \%)$ FEPV.

The vaginal vault was stated as the site of origin in 31 granulation tissue polyps and three FEPV, whereas 14 granulation tissue polyps and 31 FEPV had been removed from the anterior, posterior, or lateral wall of the vagina. In 19 granulation tissue polyps and 31 FEPV the site of origin was not stated. 
Table 1 Histological findings in stroma of 129 vaginal polyps

\begin{tabular}{|c|c|c|c|c|c|c|c|c|c|c|}
\hline \multirow[b]{3}{*}{ Polyp type } & & \multicolumn{9}{|c|}{ Histological features } \\
\hline & & \multicolumn{2}{|c|}{ Mast cells } & \multicolumn{2}{|c|}{ Multinucleated cells } & \multicolumn{2}{|c|}{ Cellularity } & \multicolumn{2}{|c|}{ Mitoses } & \multirow{2}{*}{$\begin{array}{l}\begin{array}{l}\text { Atypical } \\
\text { cells present }\end{array} \\
\text { Yes } / \mathrm{No}\end{array}$} \\
\hline & & $0 /+^{\star}$ & $++^{\star}$ & $01+$ & ++ & $\begin{array}{l}\text { Low/ } \\
\text { Medium }\end{array}$ & High & $0 /+$ & ++ & \\
\hline Granulation tissue polyps & $(\mathrm{n}=64)$ & 61 & 3 & 55 & 9 & 7 & 57 & 64 & 0 & No \\
\hline Fibroepithelial polyps: & $(n=65)$ & & & & & & & & & \\
\hline Collageneous & $(\mathbf{n}=30)$ & 25 & 5 & 20 & 10 & 29 & 1 & 30 & 0 & No \\
\hline Myxoid & $(\mathrm{n}=19)$ & 7 & 12 & 14 & 5 & 19 & 0 & 19 & 0 & No \\
\hline Mixed & $(\mathrm{n}=15)$ & 5 & 10 & 12 & 3 & 14 & 1 & 15 & 0 & No \\
\hline Atypical & $(\mathrm{n}=1)$ & 1 & & & 1 & & 1 & & 1 & Yes \\
\hline All & & 99 & 30 & 101 & 28 & 69 & 60 & 128 & 1 & \\
\hline
\end{tabular}

$\star_{0} /+=$ none or sparse.

$++=$ many.

The diameters of the polyps ranged from 0.2 $\mathrm{cm}-3.5 \mathrm{~cm}$ (mean (SEM) $0.9(0.06) \mathrm{cm})$. The mean (SEM) diameters of the various polyp types were as follows: granulation tissue polyps $0.7(0.1) \mathrm{cm}$; collagenous FEPV $1.0(0.1) \mathrm{cm}$; myxoid FEPV $1.4(0.2) \mathrm{cm}$; mixed FEPVs $1 \cdot 1$ $(0 \cdot 1) \mathrm{cm}$. One atypical polyp had a diameter of $0.9 \mathrm{~cm}$. Twenty four of $65(37 \%)$ FEPV were greater than $1 \mathrm{~cm}$ compared with 19 of 64 (14\%) granulation tissue polyps. The largest polyp was a myxoid FEPV.

Multinucleated giant cells of foreign body type were observed in nine of 64 granulation tissue polyps (table 1). Giant cells with an appearance more akin to Langhans' cells were commonly found in FEPV, and were observed in relatively large numbers in five of 19 myxoid FEPV (fig 4). In collagenous FEPV the giant cell nuclei overlapped conspicuously, and the cytoplasm was relatively sparse (fig 1 ). The cells, although multinucleated, had the regular appearance of their nuclei, and were not considered atypical. They were found with about equal frequency in the various age groups (data not shown).

Mitoses were absent in most FEPV, but were observed in moderate numbers among fibroblasts and endothelial cells in granulation tissue polyps. Collagenous FEPV exhibited a cellularity similar to that of normal vaginal mucosa; myxoid polyps were mostly less cellular. A conspicuous number of mast cells were found in 27 of $65(43 \%)$ FEPV and in three of $64(5 \%)$ granulation tissue polyps (table 1). They were most numerous in some of the myxoid FEPV. There was no "cambium layer" in the subepithelial zone in any of the polyps, and no cytoplasmatic cross-striation was observed in the stromal cells.

One of the polyps contained clearly atypical stromal cells with enlarged, bizarre, hyperchromatic, and occasional multiple nuclei, and a large number of mitoses, some of which had abnormal mitotic figures (figs $5 \mathrm{~A}$ and $\mathrm{B}$ ). The cellularity was varied but generally increased compared with the rest of the FEPV. This polyp had been excised from a grape-like mass in the vaginal fornix of a 20 year old primipara at 28 weeks of an uncomplicated pregnancy. She had a normal delivery at term. A few days later a partly necrotic polyp presented in the entrance to the vagina. Outside necrotic areas, the histological picture was similar to that of the former polyp. Clinical checkups during the following year showed no local recurrences and no metastases or any other signs of malignant disease.

Table 2 shows the immunohistochemical findings in the randomly selected polyps. Desmin positive mono- and multinucleated stromal cells were found exclusively in myxoid and mixed FEPV (fig 6). Vascular endothelium was stained with varying intensity for vimentin in all polyps. All granulation tissue polyps also contained scattered vimentin positive stromal cells, and most FEPV contained numerous stromal cells with intense cytoplasmic staining for vimentin. Positive nuclear staining for

Table 2 Immunohistochemical findings in 21 selected vaginal polyps

\begin{tabular}{|c|c|c|c|c|c|c|c|c|c|c|c|c|c|}
\hline \multirow[b]{3}{*}{ Polyp type } & & \multicolumn{12}{|c|}{ Staining reaction ${ }^{\star}$} \\
\hline & & \multicolumn{2}{|c|}{$\begin{array}{l}\text { Desmin } \\
\text { staining }\end{array}$} & \multicolumn{2}{|c|}{$\begin{array}{l}\text { Vimentin } \\
\text { staining }\end{array}$} & \multicolumn{2}{|c|}{$\begin{array}{l}\text { Myoglobin } \\
\text { staining }\end{array}$} & \multicolumn{2}{|c|}{$\begin{array}{l}\text { AAT† } \\
\text { staining }\end{array}$} & \multicolumn{2}{|c|}{$\begin{array}{l}\text { Muramidase } \\
\text { staining }\end{array}$} & \multicolumn{2}{|c|}{$\begin{array}{l}\text { ER }+ \\
\text { staining }\end{array}$} \\
\hline & & 0 & + & 0 & + & 0 & + & 0 & + & 0 & + & 0 & + \\
\hline $\begin{array}{l}\text { Granulation polyps } \\
\text { Fibroepithelial polyps: }\end{array}$ & $(\mathrm{n}=5)$ & 5 & 0 & 0 & 5 & 5 & 0 & 3 & 2 & 5 & 0 & 5 & 0 \\
\hline Collageneous & $(n=5)$ & 5 & 0 & 1 & 4 & 5 & 0 & 5 & 0 & 5 & 0 & 2 & 3 \\
\hline Myxoid & $(\mathrm{n}=5)$ & 0 & 5 & 0 & 5 & 5 & 0 & 3 & 2 & 3 & 2 & 0 & 5 \\
\hline Mixed & $(n=5)$ & 2 & 3 & 2 & 3 & 5 & 0 & 2 & 3 & 3 & 2 & 3 & 2 \\
\hline Atypical & $(\mathrm{n}=1)$ & 1 & - & - & 1 & 1 & - & 1 & - & 1 & - & 1 & - \\
\hline
\end{tabular}

${ }^{\star} 0=$ no staining

$+=$ positive staining

$\dagger=\alpha$-1-antitrypsin.

$\ddagger=$ oestrogen receptor 


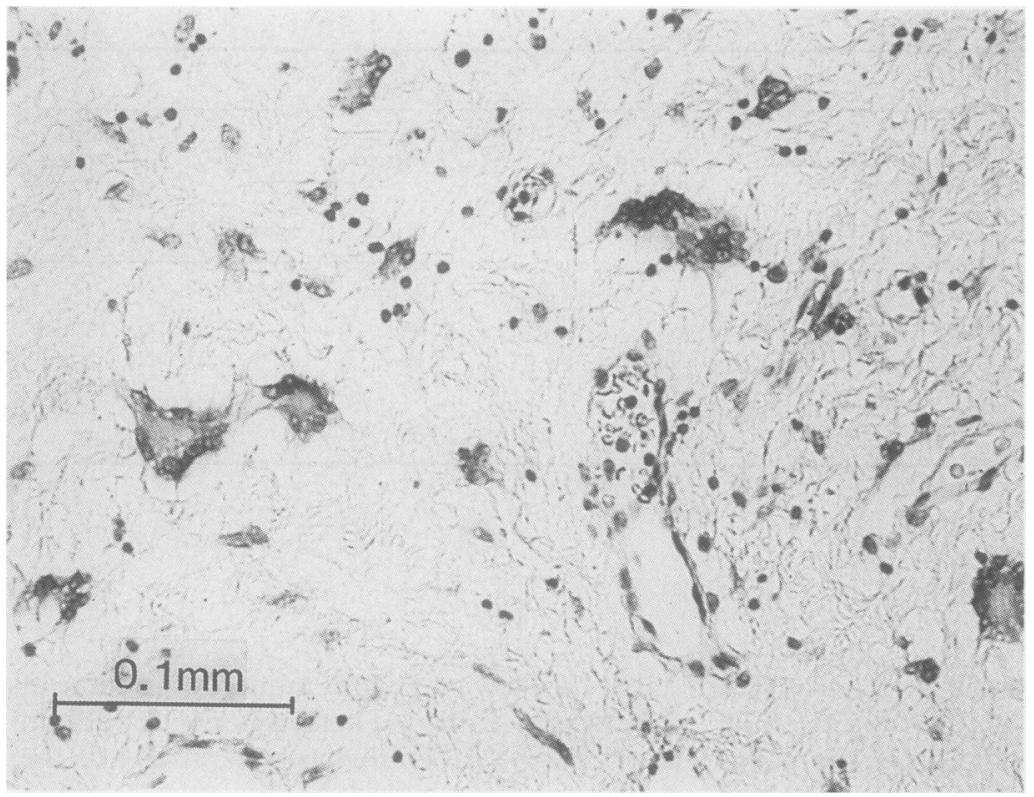

Figure 4 Characteristic multinucleated stromal cells of a myxoid FEPV. Note the abundant cytoplasm and the regular outline of the nuclei (HES).

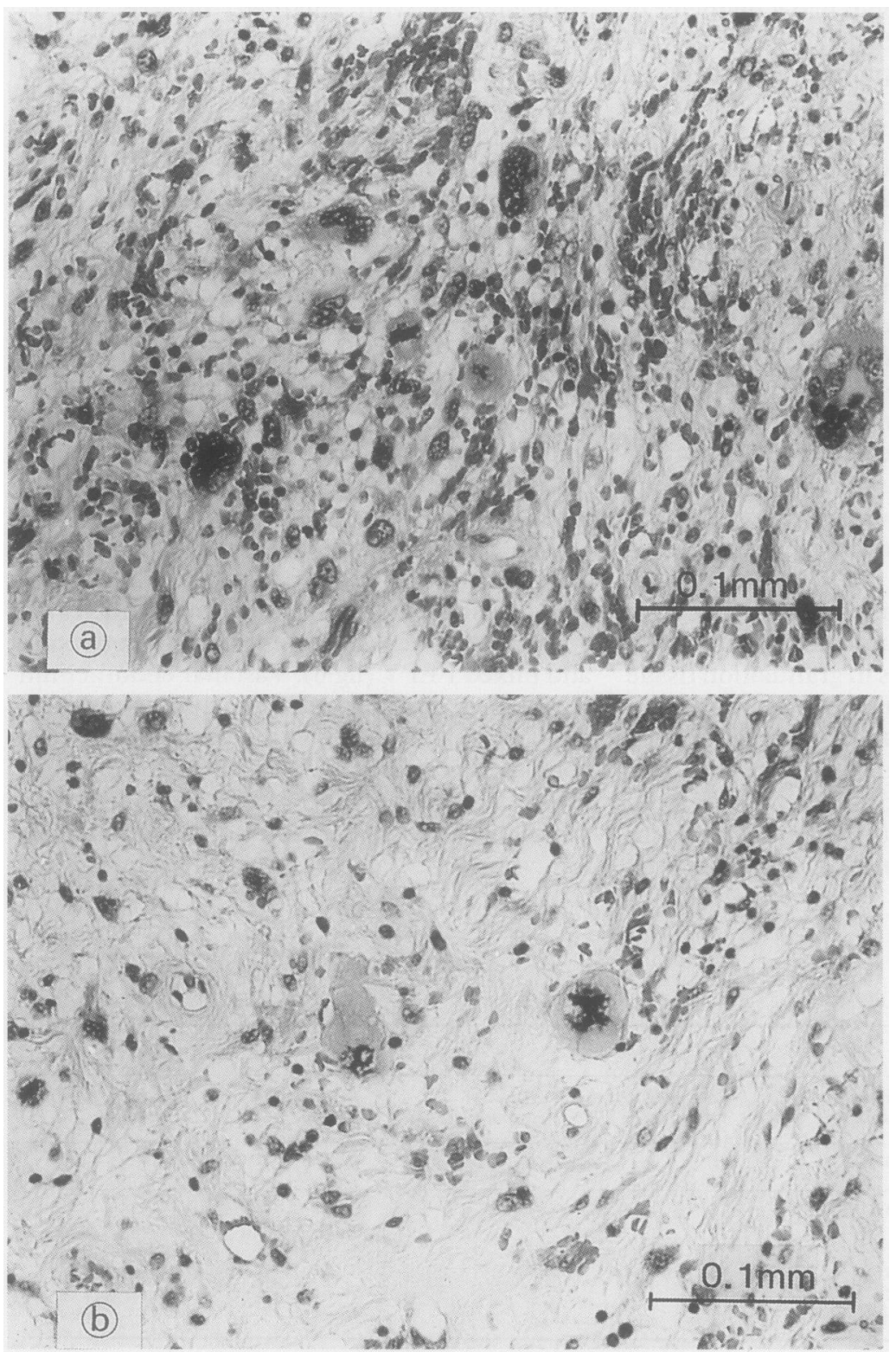

Figure 5 Histological features of an atypical vaginal polyp with bizarre, hyperchromatic, and occasional multinucleated cells $(A)$, and atypical mitoses (B) (HES). oestrogen receptor was observed in mono- and multinucleated stromal cells in 10 of 15 FEPV. A few scattered cells in some of the polyps stained positively for $\alpha$-1-antitrypsin and muramidase. Myoglobin positive cells were not observed in any of the polyps.

\section{Discussion}

This study has shown that FEPV are common benign lesions. They demonstrate a considerable spectrum of histological appearances as also emphasised by Mucitelli et al. ${ }^{12}$ FEPV and granulation tissue polyps occurred with about equal frequency in this series and shared some cytological, histological, and immunohistochemical features. The picture of FEPV has been compared with that of nodular fasciitis, self-limiting overgrowths of connective tissue, ${ }^{8}$ and FEPV have been considered to be hyperplasias of the subepithelial myxoid zone of the normal vaginal mucosa. ${ }^{15}$ Others have suggested that FEVP with atypical stromal cells should be regarded as benign counterparts to sarcoma botryoides, ${ }^{7}$ hamartomas, ${ }^{1}$ or myofibroblastomas. ${ }^{11}$ Mucitelli et al provided evidence that stromal cells of FEPV are collections of functional fibroblasts that may be capable of differentiating along two or more cell lines. ${ }^{12}$ Cells with an appearance consistent with a fibroblastic and myofibroblastic origin were observed in most of the FEVP that were selected for immunohistochemical examination in the present series. The presence of myofibroblasts and mast cells in FEPV may reflect that FEPV originate from an exuberant granulation tissue reaction following some local injury to the vaginal mucosa, as has been suggested by others. ${ }^{12} \mathrm{~A}$ histiocytic origin for the stromal cells could not be confirmed in this series. ${ }^{7}$

Although myofibroblasts have long been recognised in human granulation tissue, ${ }^{16}$ we were not able to show the presence of desmin positive cells in the granulation polyps selected for the immunohistochemical study. Myofibroblasts are considered important for the contraction of granulation tissue. ${ }^{16}$ As they could not be shown in granulation tissue polyps we suggest that granulation tissue polyps may develop when granulation tissue does not contract properly due to delayed differentiation of myofibroblasts. An extensive search in the Medline Database covering 1972 to June 1991 leads us to believe that this pathogenetic mechanism for granulation tissue polyps has not been reported. We also suggest that myxoid FEPV develop from granulation tissue polyps through proliferation in myxoid areas of cells with delayed myofibroblastic differentiation. Collagenous FEPV may represent old polyps with dense stroma that have contracted. The relatively sparse desmin negative cytoplasm in the multinucleated stromal cells in collagenous FEPV may reflect that these cells are old myofibroblasts that have (temporarily?) lost their contractile elements.

We were unable to show that granulation tissue polyps and FEPV had similar site distributions in the present series. This would 

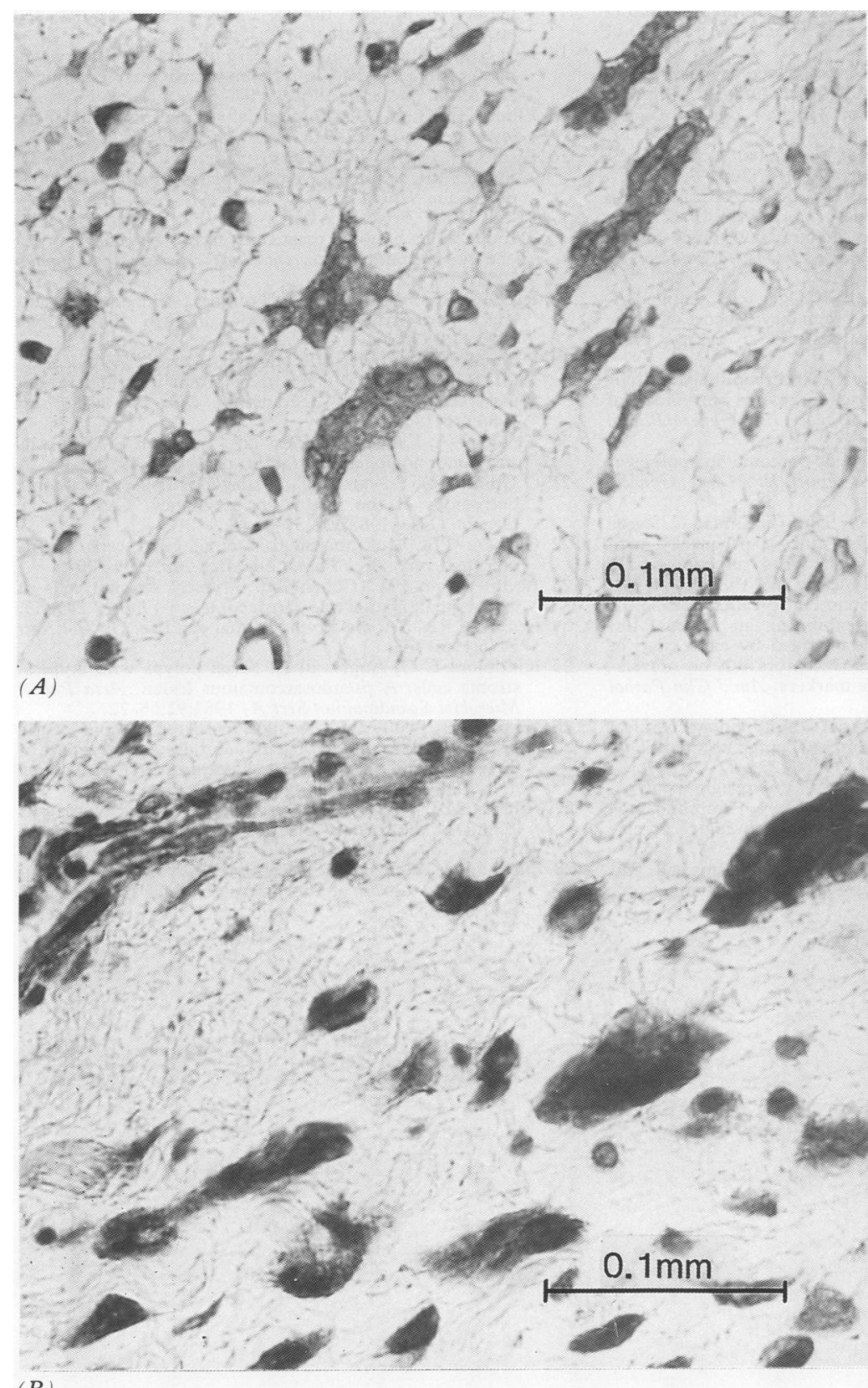

(B)

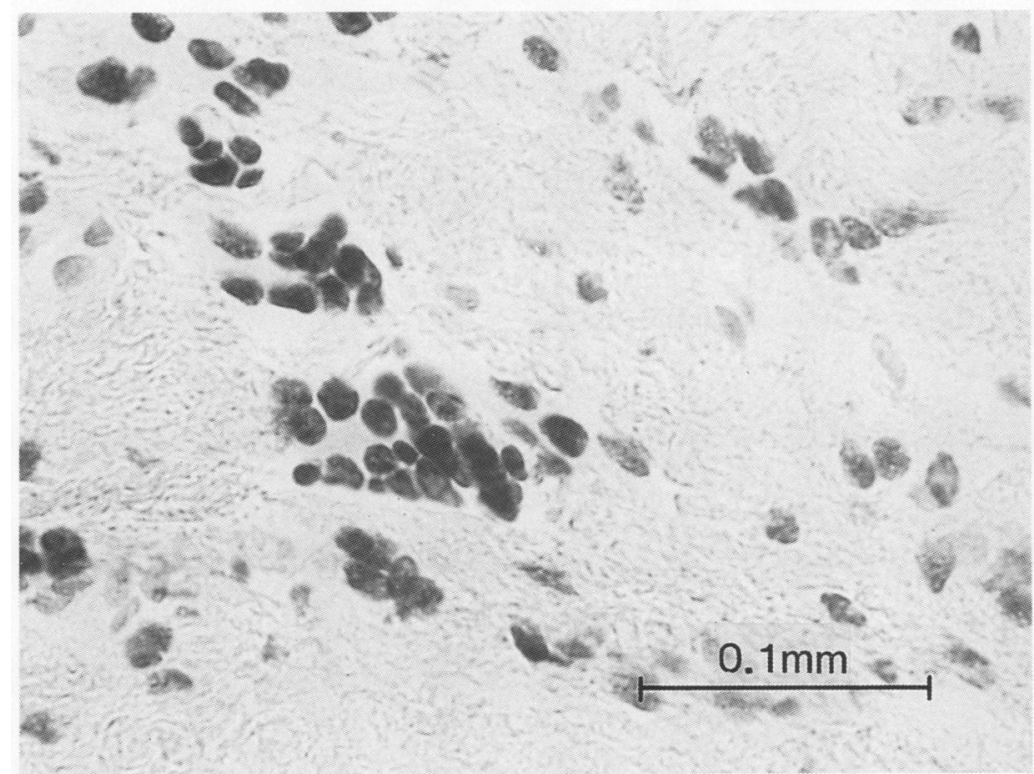

(C)

Figure 6 Micrographs from a myxoid fibroepithelial polyp showing mono- and multinucleated stromal cells with positive cytoplasmic immunostaining for desmin $(A)$, vimentin $(B)$, and nuclear labelling of oestrogen receptors $(C)(P A P)$. have strengthened our argument that one polyp derives from the other. On the contrary, there was a trend for granulation tissue polyps to predominate in the vaginal vault, whereas FEPV seemed to occur more commonly at other sites of the vaginal wall. Unfortunately, however, in 50 of the 129 cases the site of origin of the polyps was not stated on the histology request form.

Mast cells are common components of connective tissues. They were frequently observed among the stromal cells of the polyps in the present series. Similar findings have recently been pointed out by others. ${ }^{11}$ There is evidence that mast cells interact with stromal cells, stimulate cellular and vascular proliferation, and promote matrix degradation. ${ }^{17-20}$ They may have an important role among factors modulating involution and organisation of granulation tissue, and growth of tumours.

The results of the present study have confirmed that stromal cells in FEPV may contain oestrogen receptors. ${ }^{10}$ Notably, many so-called pseudo-sarcomatous polyps of the vagina have occurred during pregnancy. ${ }^{4-921}$ The role of hormonal stimulation in the pathogenesis of FEPV is not known, however, and FEPV with atypical stromal cells have also been reported in non-pregnant women, in nulligravida, and in postmenopausal women. ${ }^{13-5891220}$ Oestrogen receptor positive cells could not be observed in the atypical polyp in our series. As only one of the polyps in the present 15 year material contained definite atypical cells (and abnormal mitoses) we believe that such lesions are rare. They may form a separate pathogenetic entity. The results of this study, however, allow no firm conclusions to be drawn as to their true nature.

A prominent finding in this series was the abundance of cytologically benign multinucleated giant cells in many FEPV. Rollason et al recently pointed to the difficulty in differentiating between multinucleation and nuclear atypia in many cells. ${ }^{11} \mathrm{~A}$ micrograph in their article nicely presents characteristic multinucleated cells of similar appearance to that observed in our series. Pleomorphic multinucleated cells have been found in the vaginal mucosa of apparently healthy women, ${ }^{1522}$ and have been called "atypical stromal cells", although they may lack definite criteria of malignancy. ${ }^{23}$ During the past decades several so-called pseudosarcomas, characterised by multinucleated cells, and with a striking resemblance to FEPV, have been reported at many different sites. ${ }^{24-28}$ It should be recognised that the presence of multinucleated cells in the absence of definite cytological atypia and abnormal mitoses most probably does not reflect a malignant process. Even the most experienced pathologist, however, would probably hesitate in diagnosing a neoplastic lesion as frankly benign when observing cytological and histological features like those of the atypical polyp in the present series, with high cellularity, atypical and bizarre nuclei, a high mitotic count and abnormal mitoses. We advise that patients with such ominous lesions should be controlled carefully for some time following removal of the lesion. 
1 Burt RL, Prichard RW, Kim BS. Fibroepithelial polyp of the vagina. A report of five cases. Obstet Gynecol 1990;47 (supp1 1):52s-4s.

2 Miettinen M, Wahlstrom T, Vesterinen E, Saksela E. Vaginal polyps with pseudosarcomatous features. A clinicopathologic study of seven cases. Cancer 1983;51:1148-51.

3 Chirayil SJ, Tobon H. Polyps of the vagina: A clinicopathologic study of 18 cases. Cancer 1981;47:2904-7.

4 Norris HJ, Taylor HB. Polyps of the vagina. A benign lesion resembling sarcoma botryoides. Cancer 1966;19:227-32.

5 Elliot GB, Path FC. Pseudo-sarcoma botryoides of the cervix and vagina in pregnancy. $J$ Obstet Gynaecol $\mathrm{Br}$ Cwlth 1967;74:728-33.

6 Mitchell M, Talerman A, Scholl JS, Ogagaki T, Cibils LA. Psudosarcoma botryoides in pregnancy: Report of a case with ultrastructural observations. Obstet Gynecol 1987; 70:522-6.

7 Østør AG, Fortune DW, Riley CB. Fibroepithelial polyps with atypical stromal cells (pseudosarcoma botryoides) of vulva and vagina. A report of 13 cases. Int J Gynecol Pathol vulva and vagin

8 Davies SW, Makanje HH. Pseuodo-sarcomatous polyps of the vagina in pregnancy. Case report. Br J Obstet Gynecol 1981;88:566-8.

9 Maeenpaeae J, Søderstrøm K-O, Salmi T, Ekblad U. Large atypical polyps of the vagina during pregnancy with concomitant human papilloma virus infection. Case report. Eur J Obstet Gynecol Reprod Biol 1988;27:65-9.

10 Hartmann C-A, Sperling M, Stein H. So-called fibroepithelial polyps of the vagina exhibiting an unusual but uniform antigen profile characterized by expression of desmin and steroid hormone receptors but no musclespecific actin or macrophage markers. Am J Clin Pathol 1990;93:604-8.

11 Rollason TP, Byrne P, Williams A. Immunohistochemical and electron microscopic findings in benign fibroepithelial and electron microscopic findings in benign fi

12 Mucitelli DR, Charles EZ, Kraus FT. Vulvovaginal polyps. Histologic appearance, ultrastructure, immunocytochemical characteristics, and clinicopathologic correlations. Int J Gynecol Pathol 1990;9:20-40.

13 Taylor CR, Burns J. The demonstration of plasma cells and other immunoglobulin containing cells in formalin-fixed, paraffin-embedded tissues using peroxidase labelled antibody. J Clin Pathol 1974;27:14-20.

14 Hsu SM, Raine L, Fanger H. Use of avidin-biotin-peroxidase complex $(\mathbf{A B C})$ in immunoperoxidase technique. Histochem Cytochem 1981;29:577-88.

15 Elliot GB, Elliot JDA. Superficial stromal reactions of the lower genital tract. Arch Pathol 1973;95:100-1.

16 Ryan GB, Cliff WJ, Gabbiani G, Irle C, Montandon D, Statkov PR, Majno G. Myofibroblasts in human granula tion tissue. Hum Pathol 1974;5:55-67.

17 Atkins FM, Friedman MM, Rao PVS, Metcalfe DD. Interactions between mast cells, fibroblasts and connective tissue components. Int Arch Allergy Appl Immun 1985;77:96-102.

18 Roche WR. Mast cells and tumors. The specific enhancement of tumor proliferation in vitro. Am J Patho 1985;119:57-64.

19 Dabbous MK, Wooley DE, Haney L, Carter LM, Nicolson GL. Host-mediated effectors of tumor invasion: role of mast cells in matrix degradation. Clin Exp Metastasis 1986;4:141-52.

20 Kessler DA, Langer RS, Pless NA, Folkman J. Mast cells and tumor angiogenesis. Int $J$ Cancer 1976;18:703-9.

21 O'Quinn AG, Edwards CL, Gallager HS. Pseudosarcoma botryoides of the vagina in pregnancy. Case report. botryoides of the vagina in

22 Clement PB. Multinucleated stromal giant cells of the uterine cervix. Arch Pathol Lab Med 1985;109:200-2.

23 Abdul-Karim FW, Cohen RE. Atypical stromal cells of lower female genital tract. Histopathology 1990;17:249-53.

24 Schinella RA. Stromal atypia in anal papillae. Dis Col Rec 1976;19:611-3.

25 Kindblom L-G, Angervall L. Nasal polyps with atypical stroma cells: A pseudosarcomatous lesion. Acta Pathol Microbiol Scandinavia (Sect A) 1984;92:65-72.

26 Young RH, Scully RE. Pseudosarcomatous lesions of the urinary bladder, prostate gland, and urethra. A report of three cases and a review of the literature. Arch Pathol Lab Med 1987;111:354-8.

27 Hughes DF, Biggart JD, Hayes D. Pseudosarcomatous lesions of the urinary bladder. Histopathology 1991;18: 67-71

28 Shekita KM, Helwig EB. Deceptive bizarre stromal cells in polyps and ulcers of the gastrointestinal tract. Cancer 1991;67:2111-7. 